\title{
INFLUENCE OF FERTILIZATION WITH THE USE OF BIOMASS ASH AND SEWAGE SLUDGE ON THE CHEMICAL COMPOSITION OF JERUSALEM ARTICHOKE USED FOR ENERGY-RELATED PURPOSES
}

\author{
Anita Zapałowska', Czesław Puchalski', Grzegorz Hury², Artur Makarewicz ${ }^{3}$ \\ ${ }^{1}$ Department of Bioenergetics and Food Analysis, University of Rzeszow, Zelwerowicza 4, 35-601 Rzeszow, \\ Poland \\ 2 Department of Agronomy, West Pomeranian University of Technology in Szczecin, 3 Papieża Pawła Vl, \\ 71-459 Szczecin, Poland \\ ${ }^{3}$ Department of Agronomy, Siedlce University of Natural Sciences and Humanities, ul. B. Prusa 14, \\ 08-110 Siedlce, Poland \\ * Corresponding author's e-mail: azapalowska@ur.edu.pl
}

Received: 2017.05.15 Accepted: 2017.08.01 Published: 2017.09.01

\begin{abstract}
The experiment was based on two factors: 4-levels of fertilization with ash from biomass - 0; I - 4.28; II - 8.57; III - $12.85 \mathrm{t}^{-h^{-1}}$ and 2-levels of fertilization with sewage sludge: $0 ; 1-30.3 t^{t} \cdot \mathrm{a}^{-1}$. The experimental plant was Jerusalem artichoke (Helianthus tuberosus L.), Gigant cultivar. The contents of nitrogen tended to increase in response to fertilization with sewage sludge and to decrease with a growing dosage of fertilization with biomass ash. The use of municipal sewage sludge as a fertilizer did not produce visible changes in the contents of six macronutrients (carbon, phosphorus, potassium, sulfir, calcium and magnesium) in overground part of Jerusalem artichoke. The use of ash at the dose of $12.8 \mathrm{t} \cdot \mathrm{ha}^{-1}$ resulted in an increase in potassium contents in the plants, to the level of $5.63 \mathrm{~g} \mathrm{~K} \cdot \mathrm{kg}^{-1}$ during the first year of trials and the trend was continued in the second year. Biomass chemical stability in 2-year experiment was noted except the content of nitrogen, cadmium and lead which were increasing while the level of sewage sludge increased. The content of zinc, copper, lead and cadmium in overground part of Jerusalem artichoke did not exceed the threshold values defined for wood pellets and briquettes by the standards set forth by DIN 51731 1996-10.
\end{abstract}

Keywords: energy plants, municipal sewage sludge, ash, fertilization, retardation of natural resources transformation

\section{INTRODUCTION}

Growing developments in agriculture for energy purposes ensure cost-effective utilisation of wastelands, fallowed and uncultivated lands [Popczyk 2008]. If properly managed, they can encourage activities that involve the rehabilitation of degraded and devastated areas, thus restoring their natural and utility values. Such activities constitute retardation processes of negatively transformed natural resources and encourages the organization of sustainable development [Kostecka 2010, 2013, Poskrobko 2010]. The issue of retardation ought to be popularized [Poskrobko and Kostecka 2016] as it enables the curtailment of several negative anthropogenic pressures, including the loss of biodiversity, emission of harmful substances into the environment, overexploitation, waste storage or space degradation. Besides the benefit of increased cultivation of energy crops, it can also result in the sustainable use of natural resources.

Another significant benefit accruing to this is the reduction of $\mathrm{CO}_{2}$ emissions in course of producing electricity, heat and fuels for transport needs. Directive 2009/28/EC of the European Parliament and of the Council of 23 April 2009 on the promotion of the use of energy from re- 
newable sources, amending and revoking Directives 2001/77/CE and 2003/30/CE reflects the approach adopted by the European Parliament, according to which in 2020 the Community will achieve a $20 \%$ share of energy obtained from renewable sources [Official Journal of the European Union 5.6.2009 L 140/16]. One of the sources of renewable energy is biomass, defined as the biodegradable fraction of products, waste and residues from agriculture (including vegetal and animal substances), forestry and related industries such as fishing and aquaculture, as well as the biodegradable fraction of industrial and municipal waste [Official Journal of the European Union 5.6.2009 L 140/16].

At present biomass used in Poland for energy-related purposes originates from residues from forestry, lumber industry and agriculture, and from municipal waste. The requirements related to production of biomass designed to be used for power generation result in increased demand for and the necessity to acquire biomass from plantations of perennial energy crops. Biomass energy will be a decisive factor which will for many years enable Poland to comply with its international obligations connected with increasing the share of renewable energy sources in the total energy balance of the country [Budzyński and Bielski 2004]. The choice of energy crops for cultivation depends on the climate and soil conditions, availability and cost of reproductive material, market demand for the biomass, technological, organizational and economic conditions and other [Szczukowski and Stolarski 2013]. The factor significantly impacting the choice of a perennial energy crop for cultivation is the biomass yield feasible in the specific farming conditions. This depends on a number of factors: genetic and somatic quality of the planting material, the applied agro-technological treatments, soil fertility, weather conditions, success of the crop in competition with weeds, as well as damage caused by insects, diseases and animals. Another factor impacting the choice of crops, related to relevant environmental issues, is the chemical composition of the plant because it directly affects the quality of the products resulting from utilization of the plant as a source of energy. Perennial plants yielding lignocellulosic biomass are much more productive as a source of energy than typical agricultural crops [Börjesson 1996].

The crops cultivated for biomass, which are favoured by the climate of Central Europe, comprise three groups: trees and shrubs, grasses and perennial plants.

The cultivations designed to produce low-size lumber, in course of short-term rotations, include: willow (Salix L.), poplar (Populus L.) and false acacia (Robinia pseudoacacia L.). In the regions with moderate climate, the domestic species include common osier, grown in short-term, i.e. 1and 4-year, rotations.

Another group of biomass-producing plants comprises monocotyledonous energy crops, such as giant miscanthus (Miscanthus $x$ giganteus), Amur silver-grass (Miscanthus sacchariflorus), Chinese silver-grass (Miscanthus sinensis), prairie cord grass (Spartina pectinata) and tall bluestem (Andropogon gerardi). Plants of these species produce biomass in relatively large quantity; as a rule they also positively affect soil structure and fertility, as well as hydrographic conditions.

The final group of plants used for biomass comprises perennial species: Virginia mallow (Sida hermaphrodita L.), cup plant (Silphium perfoliatum L.), Japanese knotweed (Polygonum cuspidatum) and Jerusalem artichoke (Helianthus tuberosus L.). Widespread interest in Virginia mallow in Poland accompanied the idea that biomass obtained from this plant could be utilized as a source of energy because the crop can grow in Polish climate, in soils of medium and poor quality, including wasteland and sandy soils classified as grade five [Kwiatkowski 2012].

The assortment of plant biomass is being increased by including new plant species which grow in poor quality soil and produce large quantities of dry biomass; hence more and more land is designated for cultivation of Jerusalem artichoke, otherwise known as topinambour. Helianthus tuberosus L. is a crop plant representing aster family (Asteraceae), closely related to common sunflower (Helianthus annuus). Helianthus tuberosus $L$., which grows to the height of 2-4 metres, has upright stem with a circular cross-section, and diameter up to $2.4 \mathrm{~cm}$. Its large leaves reach the length of $20 \mathrm{~cm}$, and are arranged on the opposite sides of the stem, alternately to one another; in shape broad ovoid-acute, with dentate edges, covered with rough hair [Stanley and Nottingham 2007]. An advantage of this species is the fact that it can regenerate for years; hence there is no need for planting it every year. According to some researchers, underground tubers of the plant could be used as animal feed, yet this application is still not very common. Due to this a few years 
ago an idea was proposed that above ground part of Jerusalem artichoke biomass could be used as combustion fuel. The species is characterized by considerable flexibility and it can effectively adjust to the climate warming. Jerusalem artichoke is quite undemanding as far as the climate goes; the plant copes well with changing weather conditions and low temperatures, yet the species benefits most from warm and humid weather. It also tolerates water shortage relatively well [Conde et al. 1991]. Jerusalem artichoke may constitute a significant competition for other plants used as animal feed or for industrial purposes. It is suitable for versatile uses - as source of energy, animal feed, as well as for dietary, medicinal and recultivation purposes. Topinambour is known for high intensity of photosynthesis, and because of this in many countries it has been investigated for its usefulness as a bioenergy crop [Chabbert et al. 1985, Scholz and Ellerbrock 2002, Curt et al. 2006, Kwaśniewski et al. 2010]. Dry overground part of Jerusalem artichoke can be directly incinerated in furnaces adjusted to biomass combustion or co-combustion with coal. They can also be used for production of briquettes and pellets. Calorific value of harvested Jerusalem artichoke biomass amounts to approx. $14.7 \mathrm{MJ} \cdot \mathrm{kg}^{-1}$ [Komorowicz et al. 2009].

The present study was designed to examine the influence of fertilizers based on municipal sewage sludge and ash obtained from biomass of coniferous trees on the changes in the contents of macroand microelements in dry matter of overground part of Jerusalem artichoke (Helianthus tuberosus L), Gigant cultivar. The present findings and data reported by other researchers provided evidence for comparison of topinambour with other energy crops in terms of chemical composition.

\section{MATERIALS AND METHODS}

\section{Experimental conditions}

The study was conducted in a field left uncultivated for 8 years located in Ujkowice near Przemyśl $\left(49.85^{\circ} \mathrm{N}, 22.72^{\circ} \mathrm{E}\right)$, in 2013 and 2014. The experimental plant was Jerusalem artichoke
(Helianthus tuberosus L.), Gigant cultivar. The experiment was based on two factors: 4-levels of fertilization with ash from biomass - 0 ; I - 4,28; II - 8,57; III - 12,85 $t \cdot$ ha $^{-1}$ and 2-level of fertilization with sewage sludge $-0 ; 1-30,3 \mathrm{t} \cdot \mathrm{ha}^{-1}$. The experiment was carried out in accordance with split-plot design, with three replications. The plot comprised an area of $24 \mathrm{~m}^{2}$. The soil, with a granulometric composition of silt loam, belonging to the agricultural heavy soil class, suitable for farming purposes complex IV, was characterized with acidic reaction. The contents of elements available for plants: phosphorus and potassium at a medium level, and magnesium - very high. The total contents of metals in the soil did not exceed values accepted as medium. In accordance with applicable laws, municipal sewage sludge can be applied to this kind of soil [Journal of Laws 2010 No. 137 item 924].

Sewage sludge used in the experiment had been subjected to fermentation, dehydration and hygienization with lime, and was acquired from the Municipal Treatment Plant in Przemyśl. Chemical composition of the sewage sludge has been presented in Table 1. Identified in the sewage sludge, the contents of zinc, copper, lead, chromium, nickel, cadmium and mercury did not exceed the values specified as acceptable in Regulation of the Minister of Environment of 13 July 2010 on municipal sewage sludge [Journal of Laws 2010 No. 137 item 924]. In terms of its chemical composition the sewage sludge complied with standards defined for organic fertilizers, as specified by the Regulation of the Minister of Agriculture and Rural Development on the implementation of certain provisions of the act on fertilizers and fertilizing [Journal of Laws 2008 No. 119 item 765]. According to the assessment performed by SGS EKO-PROJEKT Laboratory in Pszczyna, the sewage sludge did not pose any sanitary hazards.

The applied ash from coniferous trees was acquired from Tartak Olczyk Sp. Z o.o. from Świdno near Krasocin. It originated from incinerated waste and woodchips of coniferous trees: spruce, pine and larch. Chemical composition of the ash has been presented in Table 2. The ash

Table 1. Chemical composition of sewage sludge, Municipal Treatment Plant in Przemyśl

\begin{tabular}{|c|c|c|c|c|c|c|c|c|c|c|c|c|}
\hline Element & $\mathrm{pH}$ & $\mathrm{N}$ & $\mathrm{P}$ & $\mathrm{Ca}$ & $\mathrm{Mg}$ & $\mathrm{Zn}$ & $\mathrm{Cu}$ & $\mathrm{Ni}$ & $\mathrm{Cr}$ & $\mathrm{Cd}$ & $\mathrm{Pb}$ & $\mathrm{Hg}$ \\
\hline Unit & $\mathrm{pH}$ & \multicolumn{8}{|c|}{$\left[\mathrm{g} \cdot \mathrm{kg}^{-1} \mathrm{~d} . \mathrm{w}.\right]$} \\
\hline Contents & 7.4 & 4.24 & 1.60 & 2.80 & 0.64 & 1053 & 171.5 & 61.2 & 61.2 & 1.60 & 42.7 & 1.33 \\
\hline
\end{tabular}


Table 2. Chemical composition of ash, Tartak Olczyk Sp. Z o.o. Świdno

\begin{tabular}{|c|c|c|c|c|c|c|c|c|c|c|c|c|c|}
\hline Element & $\mathrm{pH}$ & $\mathrm{N}$ & $\mathrm{P}$ & $\mathrm{K}$ & $\mathrm{Ca}$ & $\mathrm{Mg}$ & $\mathrm{Zn}$ & $\mathrm{Cu}$ & $\mathrm{Ni}$ & $\mathrm{Cr}$ & $\mathrm{Cd}$ & $\mathrm{Pb}$ & $\mathrm{Hg}$ \\
\hline Unit & $\mathrm{pH}$ & {$[\%]$} & \multicolumn{6}{|c|}{$\left[\mathrm{g}^{-\mathrm{kg}^{-1}}\right.$ of ash $]$} \\
\hline Contents & 9.5 & 0.1 & 0.60 & 2.34 & 20.6 & 1.14 & 280 & 134 & 11.4 & 125 & 11.6 & 13.1 & 0.013 \\
\hline
\end{tabular}

from coniferous trees contained more potassium than phosphorus, and practically no nitrogen, and it had $\mathrm{pH}=9.5$. No organic carbon or nitrogen was identified in the ash (Tab.2). The total contents of cadmium and chromium in the ash from coniferous trees were higher than in the sewage sludge. On the other hand the sludge was characterized with higher total contents of nickel, zinc, lead and copper. The biomass ash, utilized in the experiment, had very low total contents of phosphorus, amounting to $0.6 \%$. As defined by the criteria for mineral soil [PN-R-04022:1996/Azl:2002] this was extremely low content. The alkaline reaction of the ash, at $\mathrm{pH}>8$, was one of the factors resulting in such low contents of this element.

In 2013, before planting, mineral and organic fertilizers were applied to the plot. The dosage of municipal sewage sludge and biomass ash was determined taking into account the contents of nitrogen and phosphorus in the municipal sewage sludge and the contents of calcium and potassium in the biomass ash, as well as the $\mathrm{pH}$ value and requirements of topinambour for fertilizers.

During 2013 and 2014 cultivation of Gigant variety of Jerusalem artichoke (Helianthus tuberosus L.) followed specific fertilization regimes. The planting material was acquired from a private grower: Vreeken's Zaden, Voorstraat 448, 3311 CX Dordrecht. The tubers were planted on 10 April 2013, at the rate of 20,000 plants $\cdot \mathrm{ha}^{-1}$. Each year, during vegetation all the plots were weeded manually. In winter the overground parts were mowed with a manual petrol strimmer. In 2013 and 2014, after the end of the vegetation period, samples of each variant were collected to examine their chemical composition. The plant samples were examined for dry weight, total carbon and nitrogen, phosphorus, potassium, calcium, magnesium and sulfur, as well as some micronutrients: sodium, zinc, copper, nickel, lead and cadmium. Part of the powdered biomass was examined in True-Spec apparatus for the contents of carbon and nitrogen (CHN module) in accordance with PN-EN 15104:2011(U). The biomass was mineralized with the use of nitric $(\mathrm{V})$ acid. After the plant material was mineralized, chemical assay (for potassium, calcium, magnesium, sodium, zinc, copper, nickel, lead, cadmium, phosphorus, nitrogen, sulfur) was performed with ICP-OES 6500 spectrometer.

\section{Statistical analysis}

Statistical analysis of the findings was based on two-way analysis of variance, with split-plot design in 2013 and 2014; number of replications $\mathrm{n}=3$. Multiple comparison of the means was performed using Tukey's test, at significance level $\alpha=0.05$. The above calculations were carried out with Statistica 10 software. $\mathrm{NIR}_{0.05}$ values were given in the tables of mean findings for the following effects: main effects of fertilization with sewage sludge (FS) and fertilization with ash (FA). The mean values for combination of FS and FA are not presented due to the lack of significant interaction between these factors.

\section{Meteorological conditions}

According to the data from the Institute of Meteorology and Water Management in Warsaw, mean total precipitation in Podkarpacie Province in 2013 was lower $(580 \mathrm{~mm})$ in comparison to the multiannual mean $(610 \mathrm{~mm})$, and in 2014 it was slightly higher $(640 \mathrm{~mm})$. In June 2013 and July 2014 there were heavy rain falls $(140 \mathrm{~mm}$ and $120 \mathrm{~mm}$ ). The rainfalls observed in July beneficially affected the level of moisture in the surface level of soil as well as growth and development of root crops. During the remaining months precipitation was significantly lower. Mean air temperature during the first vegetation season (2013), amounting to $11.2^{\circ} \mathrm{C}$, was similar to mean air temperature during the second vegetation season $\left(11.3^{\circ} \mathrm{C}\right)$; both values were slightly higher than the multiannual mean $\left(10.6^{\circ} \mathrm{C}\right)$. During the initial vegetation period (April - May) as well as at its peak (June - August) the mean monthly air temperatures were similar to the multiannual mean values. The temperatures observed from October to December were higher than the multiannual mean, on average by $2^{\circ} \mathrm{C}$. In 2014 the mean air temperature of $11.3^{\circ} \mathrm{C}$ exceeded the multiannual mean by $0.7^{\circ} \mathrm{C}$. The high temperature in Novem- 
ber supported continued vegetation. The weather conditions in December did not pose any significant hazard for the wintering plants. The temperature was favourable for the continued vegetation of the plants. Short-term decrease in air temperature, occurring locally at the ground level, did not result in excessive cooling of the soil. Hydration of the surface soil layers at the start of the vegetation period effectively secured water requirements of the plants. The weather conditions in April were also favourable for agriculture and promoted rapid growth of plants. As a result of cold spell in May, the pace of plant growth and maturation was slower. In June the agrometeorological conditions were varied just like in the coming months (Tab. 3).

\section{RESULTS AND DISCUSSION}

\section{Contents of macronutrients in biomass of energy plants}

Based on literature review, Table 4 presents mean contents of macronutrients in plants grown for biomass.

The plants listed in Table 4 are found with similar contents of three elements, carbon, hydrogen and oxygen, i.e. those which most profoundly affect calorific value of plants. The elements are the main constituents of such organic compounds as carbohydrates, proteins and fats. Nitrogen is responsible for formation of amino acids, amines, and ultimately - proteins. The contents of other macronutrients in plants are varied, and depend on the generic features of the specific plants, the developmental phase, soil and weather conditions, as well as agrotechnology. Fertilization has specifically significant effect on the content of these elements in plants [Podkówka 2012].

The findings of the experiment involving fertilization with sewage sludge and biomass ash from coniferous trees showed that the treatment did not bring a significant change in the contents of carbon in overground part of Jerusalem artichoke, Gigant cultivar. The contents of carbon were similar during the two years of the experiment and the mean value amounted to 453,5g $\mathrm{C} \cdot \mathrm{kg}^{-1} \mathrm{~d}$.w. (Table 5 and 6 ). This is consistent with data reported by Komorowicz et al. [2009] who identified the value of $458 \mathrm{~g} \mathrm{C} \cdot \mathrm{kg}^{-1} \mathrm{~d}$.w.; on the other hand this is the lowest rate in the group of plants grown for biomass (Table 4 and 5). The highest contents of carbon have been identified in false acacia (Robinia pseudoacacia L.) - 508 $\mathrm{g} \cdot \mathrm{kg}^{-1}$ d.w. [Stolarski et al. 2013].

The mean contents of nitrogen in Jerusalem artichoke (Helianthus tuberosus L.) were similar in the consecutive years of the study (Table 5 and 6). It was observed the contents of nitrogen tended to increase in response to fertilization with sewage sludge and to decrease with a growing dosage of fertilization with biomass ash. This may be justified with the fact that sewage sludge is a source of nitrogen, unlike ash which generally does not contain this element. Furthermore, the decrease in nitrogen contents coinciding with higher dosage of ash fertilizer may be linked with the growth of crop. The mean contents of nitrogen in overground part of Jerusalem artichoke, Gigant cultivar, amounted to $0,28 \mathrm{~g} \mathrm{~N} \cdot \mathrm{kg}^{-1} \mathrm{~d}$.w. and, just like in the case of carbon, this was the

Table 3. Mean monthly air temperature in ${ }^{\circ} \mathrm{C}(\mathrm{T})$ and monthly total precipitation in mm (P) during 2013-2014 and multiannual mean for 1971-2000

\begin{tabular}{|l|c|c|c|c|c|c|}
\hline \multirow{2}{*}{ Month } & \multicolumn{9}{|c|}{ Years } & \multicolumn{2}{c|}{$\begin{array}{c}\text { Multiannual mean for } \\
1971-2000\end{array}$} \\
\cline { 2 - 7 } & \multicolumn{2}{|c|}{2013} & \multicolumn{2}{c|}{2014} & $\mathrm{~T}$ & $\mathrm{P}$ \\
\cline { 2 - 7 } & $\mathrm{T}$ & $\mathrm{P}$ & $\mathrm{T}$ & $\mathrm{P}$ & 8 & 50 \\
\hline April & 8.6 & 50 & 9.2 & 50 & 13 & 80 \\
\hline May & 13.3 & 90 & 12.4 & 160 & 15 & 110 \\
\hline June & 16.6 & 140 & 15.5 & 60 & 18 & 100 \\
\hline July & 17.9 & 80 & 18.5 & 120 & 18 & 70 \\
\hline August & 17.9 & 20 & 16.3 & 80 & 14 & 70 \\
\hline September & 11.0 & 70 & 13.9 & 60 & 9 & 50 \\
\hline October & 10.1 & 20 & 9.5 & 50 & 2 & 40 \\
\hline November & 4.8 & 90 & 6.0 & 20 & -1 & 40 \\
\hline December & 1.4 & 20 & 0.5 & 40 & 10.6 & 610 \\
\hline April-Dec. & 11.2 & 580 & 11.3 & 640 & 9 & \\
\hline
\end{tabular}


Table 4. Mean contents of macronutrients in plants used for biomass

\begin{tabular}{|c|c|c|c|c|c|c|c|c|c|c|}
\hline \multirow{2}{*}{ Plant } & C & $\mathrm{H}$ & $\mathrm{O}$ & $\mathrm{N}$ & $\mathrm{P}$ & $\mathrm{K}$ & $S$ & $\mathrm{Ca}$ & $\mathrm{Mg}$ & \multirow{2}{*}{ References } \\
\hline & \multicolumn{9}{|c|}{ [g.kg-1 d.w.] } & \\
\hline Willow (Salix L.) & 471 & 61.0 & 443 & 5.40 & 0.90 & 2.60 & 0.45 & 6.80 & 0.50 & Hartmann 2014 \\
\hline Poplar (Populus L.) & 475 & 62.0 & 441 & 4.20 & 1.00 & 3.50 & 0.31 & 5.10 & 0.50 & Hartmann 2014 \\
\hline $\begin{array}{l}\text { False acacia (Robinia } \\
\text { pseudoacacia L.) }\end{array}$ & 508 & 62.0 & 421 & 13.0 & & & 0.61 & & & Stolarski et al. 2013 \\
\hline $\begin{array}{l}\text { Giant miscanthus } \\
\text { (Miscanthus } x \text { giganteus) }\end{array}$ & 475 & 62.0 & 470 & 7.30 & 1.14 & 8.70 & 1.50 & 1.81 & 0.64 & \begin{tabular}{|l|} 
Hartmann 2014 \\
Kristensen 2003 \\
\end{tabular} \\
\hline $\begin{array}{l}\text { Prairie cord grass (Spartina } \\
\text { pectinata) }\end{array}$ & 488 & 54.3 & 384 & 11.1 & 0.45 & 3.70 & 2.30 & 2.78 & 0.22 & \begin{tabular}{|l} 
Kowalczyk-Juśko \\
2013 \\
Helios 2014 \\
\end{tabular} \\
\hline $\begin{array}{l}\text { Tall bluestem (Andropogon } \\
\text { gerardi) }\end{array}$ & 455 & 61.0 & 415 & 11.4 & 1.90 & 14.9 & 1.60 & 5.00 & 1.60 & Hartmann 2014 \\
\hline $\begin{array}{l}\text { Virginia mallow (Sida } \\
\text { hermaphrodita L.) }\end{array}$ & 473 & 62.5 & 430 & 3.20 & 0.50 & 4.23 & 0.53 & 7.46 & 9.56 & $\begin{array}{l}\text { Borkowska and } \\
\text { Lipiński } 2008\end{array}$ \\
\hline $\begin{array}{l}\text { Cup plant (Silphium } \\
\text { perfoliatum L.) }\end{array}$ & 472 & & 430 & 2.47 & & & 0.47 & & & Slepetys et al. 2012 \\
\hline $\begin{array}{l}\text { Japanese knotweed } \\
\text { (Polygonum cuspidatum) }\end{array}$ & 468 & 56.9 & 420 & 3.80 & & & 0,00 & & & $\begin{array}{l}\text { Komorowicz et al. } \\
2009\end{array}$ \\
\hline $\begin{array}{l}\text { Jerusalem artichoke } \\
\text { (Helianthus tuberosus L.) }\end{array}$ & 458 & 60.8 & 391 & 3.10 & 1.58 & 30.5 & 1.08 & 0.78 & 0.46 & $\begin{array}{l}\text { Komorowicz et al. } \\
2009 \\
\text { Skiba } 2014\end{array}$ \\
\hline
\end{tabular}

Table 5. Effect of fertilization with biomass ash from coniferous trees (FA) in the contents of macronutrients in overground part of topinambour, Gigant cultivar, $\left[\mathrm{g} \cdot \mathrm{kg}^{-1} \mathrm{~d} . \mathrm{w}.\right]$

\begin{tabular}{|c|c|c|c|c|c|c|c|}
\hline \multirow{2}{*}{ Years } & \multirow{2}{*}{ Element } & \multicolumn{4}{|c|}{$\mathrm{FA}\left[\mathrm{t} \mathrm{ha}^{-1}\right]$} & \multirow{2}{*}{ Mean } & \multirow{2}{*}{$\mathrm{NIR}_{0.05}$ for: } \\
\hline & & 0 & 4.28 & 8.57 & 12.85 & & \\
\hline \multirow{7}{*}{2013} & Carbon & 455 & 446 & 456 & 457 & 454 & r.n. \\
\hline & Nitrogen & 0.33 & 0.36 & 0.22 & 0.23 & 0.28 & r.n. \\
\hline & Phosphorus & 0.35 & 0.47 & 0.22 & 0.34 & 0.35 & r.n. \\
\hline & Potassium & 3.50 & 4.58 & 5.24 & 5.63 & 4.73 & 1.72 \\
\hline & Sulfur & 0.42 & 0.38 & 0.37 & 0.37 & 0.39 & r.n. \\
\hline & Calcium & 7.72 & 6.98 & 6.56 & 5.98 & 6.81 & r.n. \\
\hline & Magnesium & 1.38 & 1.12 & 1.13 & 1.26 & 1.22 & r.n. \\
\hline
\end{tabular}

Explanation: r.n.- insignificant differences

lowest value, compared to those reported in other plants grown for biomass (Table 4, 5 i 6). Komorowicz et al. [2009] report the mean quantity of nitrogen in topinambour at the higher level of $3.10 \mathrm{~g} \mathrm{~N} \cdot \mathrm{kg}^{-1}$ d.w.

Literature review shows significantly varied contents of phosphorus in above ground part of Jerusalem artichoke. For instance, Skiba [2014] reported the value of $1.58 \mathrm{~g} \mathrm{P} \cdot \mathrm{kg}^{-1} \mathrm{~d}$.w., while Sawicka et al. [2015], who examined impact of nitrogen fertilizers, obtained the value of $3.16 \mathrm{~g}$ $\mathrm{P} \cdot \mathrm{kg}^{-1} \mathrm{~d}$.w. Other plants grown for biomass were characterized with varied phosphorus contents, ranging from 0.45 to $1.90 \mathrm{~g} \mathrm{P} \cdot \mathrm{kg}^{-1} \mathrm{~d}$.w. (Table 4). The mean contents of phosphorus in the cultivated Jerusalem artichoke in the subsequent years amounted to 0.35 and $0.49 \mathrm{~g} P \cdot \mathrm{kg}^{-1}$ d.w. (Table 5 and 6).
Following the experiment whereby soil was supplemented with ash from coniferous trees, there was only an increase in the contents of potassium. The use of ash at the dose of $12.85 \mathrm{t} \cdot \mathrm{ha}^{-1}$ resulted in an increase in potassium contents in the plants, to the level of $5.63 \mathrm{~g} \mathrm{~K} \mathrm{~kg}^{-1} \mathrm{~d}$.w. during the first year of trials (in 2013) and the trend was continued in the second year (Table 6). According to Jankowska-Huflejt [2014] the threshold value of potassium in animal feed amounts to $8.3 \mathrm{~g} \mathrm{~K}^{\mathrm{k}} \mathrm{kg}^{-1}$ d.w. Given the above, overground part of Jerusalem artichoke could also be used as a source of fodder. Compared to other energy crops in which potassium contents ranged from 2.60 to $14,9 \mathrm{~g} \mathrm{~K} \mathrm{~kg}^{-1} \mathrm{~d}$.w. the relevant value in above ground part of Jerusalem artichoke can be recognized as average (Table 4 and 6). 
Table 6. Effect of fertilization with municipal sewage sludge (FS) in the contents of macronutrients in overground part of topinambour, Gigant cultivar, $\left[\mathrm{g} \cdot \mathrm{kg}^{-1} \mathrm{~d}\right.$.w.]

\begin{tabular}{|c|c|c|c|c|c|}
\hline \multirow{2}{*}{ Years } & \multirow{2}{*}{ Element } & \multicolumn{2}{|c|}{$\mathrm{FS}\left[\mathrm{t} \mathrm{ha}{ }^{-1}\right]$} & \multirow{2}{*}{ Mean } & \multirow{2}{*}{$\mathrm{NIR}_{0.05}$ for: } \\
\hline & & 0 & 30.3 & & \\
\hline \multirow{7}{*}{2013} & Carbon & 452 & 455 & 454 & r.n. \\
\hline & Nitrogen & 0.26 & 0.30 & 0.28 & 0.03 \\
\hline & Phosphorus & 0.34 & 0.35 & 0.35 & r.n. \\
\hline & Potassium & 4.93 & 4.53 & 4.73 & r.n. \\
\hline & Sulfur & 0.37 & 0.40 & 0.39 & r.n. \\
\hline & Calcium & 6.46 & 7.16 & 6.81 & r.n. \\
\hline & Magnesium & 1.13 & 1.31 & 1.22 & r.n. \\
\hline \multirow{7}{*}{2014} & Carbon & 452 & 454 & 453 & r.n. \\
\hline & Nitrogen & 0.26 & 0.31 & 0.28 & 0.04 \\
\hline & Phosphorus & 0.49 & 0.49 & 0.49 & r.n. \\
\hline & Potassium & 4.49 & 4.71 & 4.60 & r.n. \\
\hline & Sulfur & 0.41 & 0.39 & 0.40 & r.n. \\
\hline & Calcium & 6.98 & 6.02 & 6.50 & r.n. \\
\hline & Magnesium & 1.08 & 1.03 & 1.05 & r.n. \\
\hline
\end{tabular}

Explanation: see table 5

Analysis of above ground part of Jerusalem artichoke in terms of sulfur contents shows that the use of ash from coniferous trees, in varied doses, did not produce any effect. The content of sulfur was at the level of $0.4 \mathrm{~g} \mathrm{~S}^{\mathrm{kg}}{ }^{-1} \mathrm{~d}$.w. (Table 5 and 6). This is a similar value as that reported in such energy crops as willow and poplar (Table 4).

Total calcium and magnesium did not depend on the applied fertilization with ash from coniferous trees (Table 5 and 6). For comparison, forage crops are found with the contents of calcium in

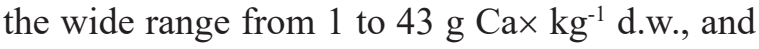
the threshold value recognized for the contents of

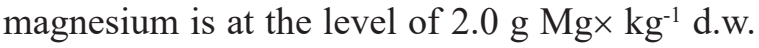
[Kulik 2009]. During the second experimental year, above ground part of Jerusalem artichoke was found with the mean contents of calcium at $6.50 \mathrm{~g} \mathrm{Cakg}^{-1}$ d.w., and magnesium amounting to $1.05 \mathrm{~g} \mathrm{Mg} \mathrm{kg}^{-1}$ d.w.; neither value exceeded the parameters set forth for forage crops, which broadens the range of potential uses for the plant. The contents of calcium in overground part of Jerusalem artichoke are nearly similar to those in wood of willow (Salix L.) (Table 4, 5 and 6). In the case of magnesium, the contents characteristic for above ground part of Jerusalem artichoke, are comparable to those in tall bluestem (Andropogon gerardi) (Table 4, 5 and 6).

The use of municipal sewage sludge as a fertilizer did not produce visible changes in the contents of macronutrients (carbon, phosphorus, potassium, sulfur, calcium and magnesium) in overground part of Jerusalem artichoke (Helian- thus tuberosus L.), Gigant cultivar (Tab.6). As an exception, the contents of nitrogen increased as a result of fertilization with sewage sludge. Compared to other crop plants, overground part of Jerusalem artichoke (Helianthus tuberosus L.), Gigant cultivar, was characterized with lower contents of carbon, nitrogen and phosphorus. For comparison, Skiba [2014] presented results of a study investigating mineral composition of above ground part of topinambour and reported the highest content of potassium ( $\left.30.54 \mathrm{~g} \mathrm{~K}^{\mathrm{k} g}{ }^{-1}\right)$; the remaining macroelements were identified as follows: nitrogen $\left(17.04 \mathrm{~g} \mathrm{~N} \cdot \mathrm{kg}^{-1}\right)>$ calcium $(1.58 \mathrm{~g}$ Cakg-1 $)>$ magnesium (2.39 $\left.\mathrm{g} \mathrm{Mgkg}^{-1}\right)>$ phosphorus $\left(1.58 \mathrm{~g} \mathrm{Pkg}^{-1}\right)>$ sulfur $\left(1.20 \mathrm{~g} \mathrm{~S}^{-1} \mathrm{~kg}^{-1}\right)$.

\section{Contents of micronutrients}

Findings related to the composition of microelements in dry mass of various plants grown for biomass are presented in Table 7 .

The mean contents of zinc in overground part of Jerusalem artichoke were at the level of 32.3

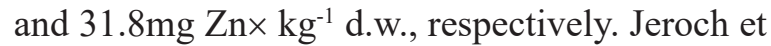
al. [1993] reported that heavily fertilized pasture

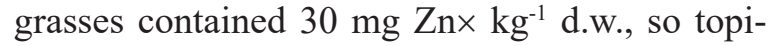
nambour can also be treated as forage material. A comparison of zinc contents shows that wood of willow and poplar contains more of this element than biomass obtained from overground parts of topinambour (Table 7, 8 and 9).

In the case of copper and nickel the use of the relevant fertilizers did not result in a change 
Table 7. Mean contents of micronutriets in plants used for biomass and threshold values for wood pellets and briquettes

\begin{tabular}{|c|c|c|c|c|c|c|}
\hline \multirow{2}{*}{ Plant } & $\mathrm{Zn}$ & $\mathrm{Cu}$ & $\mathrm{Ni}$ & $\mathrm{Pb}$ & $\mathrm{Cd}$ & \multirow{2}{*}{ References } \\
\hline & \multicolumn{5}{|c|}{$\left[\mathrm{mg} \cdot \mathrm{kg}^{-1}\right.$ d.w.] } & \\
\hline willow (Salix L.) & 67.7 & 3.22 & 0.26 & 0.10 & 0.61 & $\begin{array}{l}\text { Wandrasz and } \\
\text { Wandrasz } 2006\end{array}$ \\
\hline poplar (Populus L.) & 43.5 & 3.52 & 0.27 & 0.11 & 0.31 & $\begin{array}{l}\text { Wandrasz and } \\
\text { Wandrasz } 2006\end{array}$ \\
\hline $\begin{array}{l}\text { giant miscanthus (Miscanthus } x \\
\text { giganteus) }\end{array}$ & 24.0 & 2.18 & $1.5-3.5$ & $0.6-2$ & $0.02-0.25$ & $\begin{array}{l}\text { Kotecki } 2010 \\
\text { Kozak et al. } 2006\end{array}$ \\
\hline $\begin{array}{l}\text { prairie cord grass (Spartina } \\
\text { pectinata) }\end{array}$ & 32.9 & 2.39 & 1.41 & 3.84 & 0.26 & Helios 2014 \\
\hline $\begin{array}{l}\text { Virginia mallow (Sida hermaphrodita } \\
\text { L.) }\end{array}$ & 12.4 & 3.13 & 1.86 & 0.48 & 0.42 & $\begin{array}{l}\text { Borkowska and Lipiński } \\
\text { 2008; }\end{array}$ \\
\hline $\begin{array}{l}\text { Threshold values for wood pellets } \\
\text { and briquettes }\end{array}$ & $<100$ & $<5$ & $\begin{array}{c}\text { not } \\
\text { determined }\end{array}$ & $<10$ & $<0.5$ & DIN 51731 1996-10 \\
\hline
\end{tabular}

in the contents of these microelements in overground part of Jerusalem artichoke. Copper was found in the plants at the level of $3 \mathrm{mg} \mathrm{Cu} \times \mathrm{kg}^{-1}$ d.w., which in accordance with data reported by Kabata-Pendias [2011] is similar to the bottom level of the contents identified for instance in potatoes. The discussed plants, including Jerusalem artichoke, were characterized with similar levels of copper contents (Table 7 and 9).

The identified mean contents of nickel in above ground part of Jerusalem artichoke amount-

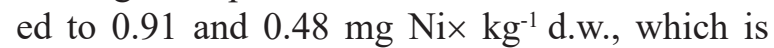
more than in willow and poplar used as biomass. Applicable standards do not specify threshold values for nickel contained in wood pellets and briquettes [DIN 51731 1996-10].

Lead is easily absorbed by plants, and it accumulates in their tissues. The mean contents of lead in overground part of Jerusalem artichoke were at the level of 0.32 and $0.21 \mathrm{mg}$ $\mathrm{Pb} \cdot \mathrm{kg}^{-1}$ d.w. Ash fertilization did not have a definitive impact on lead content in the aerial biomass of Jerusalem artichoke over the period covered by the study (Table 8). Lead content in plants indicated a declining tendency during the first year of the experimentation. During the second year, after sewage sludge was applied as fertilizer, the level of lead concentration in overground part of Jerusalem artichoke was statistically proven (Table 9). According to the data reported in the literature, energy crops vary in terms of lead content; overground part of topinambour was found with similar content to that in virginia mallow (Sida hermaphrodita L.) (Table 8, 9).

Cadmium is not needed for biological processes. The findings of an assay for cadmium content in overground part of Jerusalem arti- choke and relevant statistical calculations did not show differences in the contents of this element as a result of fertilization with ash. During the first experimental year, a higher quantity of cad-

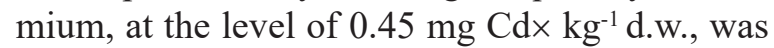
observed in plants growing in the plots fertilized with sewage sludge.

Lead and cadmium contents in overground part of topinambour did not exceed threshold values specified in Commission Regulation (EU) No. 1275/2013 regarding maximum levels of cadmium and lead in animal feed, which suggests the plant may be useful for nutritional purposes [Commission Regulation (EU) No 1275/2013 7.12.2013 L 328/86].

The contents of metals (zinc, copper, lead and cadmium) in overground part of Jerusalem artichoke did not exceed threshold values defined for wood pellets and briquettes by the standards set forth by Deutsches Institut für Normung [DIN 51731 1996-10].

\section{CONCLUSIONS}

1. The use of municipal sewage sludge as a fertilizer did not produce visible changes in the contents of macronutrients (carbon, phosphorus, potassium, sulfur, calcium and magnesium) in overground part of Jerusalem artichoke (Helianthus tuberosus L.), Gigant cultivar. As an exception, the contents of nitrogen increased as a result of fertilization with sewage sludge. The highest level of wood ash fertilization $\left(12.85 \mathrm{t} \cdot \mathrm{ha}^{-1}\right)$ on the other hand resulted in increased or upward trend of potassium content in the biomass of Jerusalem artichoke. 
Table 8. Effect of fertilization with biomass ash from coniferous trees (FA) in the contents of micronutrients in overground part of Jerusalem artichoke, Gigant cultivar, $\left[\mathrm{mg} \cdot \mathrm{kg}^{-1} \mathrm{~d} . \mathrm{w}.\right]$

\begin{tabular}{|c|c|c|c|c|c|c|c|}
\hline \multirow{2}{*}{ Years } & \multirow{2}{*}{ Element } & \multicolumn{4}{|c|}{$\mathrm{FA}\left[\mathrm{t} \mathrm{ha}^{-1}\right]$} & \multirow{2}{*}{ Mean } & \multirow{2}{*}{$\mathrm{NIR}_{0.05}$ for: } \\
\hline & & 0 & 4.28 & 8.57 & 12.85 & & \\
\hline \multirow{5}{*}{2013} & Zinc & 31.4 & 31.6 & 34.3 & 31.9 & 32.3 & r.n. \\
\hline & Copper & 3.65 & 3.06 & 2.74 & 3.02 & 3.12 & r.n. \\
\hline & Nickel & 0.89 & 0.89 & 1.05 & 0.79 & 0.91 & r.n. \\
\hline & Lead & 0.42 & 0.31 & 0.24 & 0.29 & 0.32 & r.n. \\
\hline & Cadmium & 0.39 & 0.34 & 0.45 & 0.40 & 0.39 & r.n. \\
\hline \multirow{5}{*}{2014} & Zinc & 33.8 & 31.2 & 31.8 & 30.6 & 31.8 & r.n. \\
\hline & Copper & 2.35 & 2.86 & 2.38 & 2.41 & 2.50 & r.n. \\
\hline & Nickel & 0.42 & 0.63 & 0.54 & 0.34 & 0.48 & r.n. \\
\hline & Lead & 0.17 & 0.14 & 0.29 & 0.26 & 0.21 & r.n. \\
\hline & Cadmium & 0.37 & 0.33 & 0.42 & 0.39 & 0.38 & r.n. \\
\hline
\end{tabular}

Explanation: see table 5

Table 9. Effect of fertilization with municipal sewage sludge (FS) in the contents of micronutrients in overground part of Jerusalem artichoke, Gigant cultivar, $\left[\mathrm{mg} \cdot \mathrm{kg}^{-1} \mathrm{~d} . \mathrm{w}.\right]$

\begin{tabular}{|c|c|c|c|c|c|}
\hline \multirow{2}{*}{ Years } & \multirow{2}{*}{ Element } & \multicolumn{2}{|c|}{$\mathrm{FS}\left[\mathrm{t} \mathrm{ha}{ }^{-1}\right]$} & \multirow{2}{*}{ Mean } & \multirow{2}{*}{$\mathrm{NIR}_{0.05}$ for: } \\
\hline & & 0 & 30.3 & & \\
\hline \multirow{5}{*}{2013} & Zinc & 30.1 & 34.5 & 32.3 & r.n. \\
\hline & Copper & 2.79 & 3.45 & 3.12 & r.n. \\
\hline & Nickel & 0.82 & 0.99 & 0.91 & r.n. \\
\hline & Lead & 0.36 & 0.28 & 0.32 & r.n. \\
\hline & Cadmium & 0.34 & 0.45 & 0.39 & 0.02 \\
\hline \multirow{5}{*}{2014} & Zinc & 33.8 & 29.8 & 31.8 & r.n. \\
\hline & Copper & 2.62 & 2.38 & 2.50 & r.n. \\
\hline & Nickel & 0.53 & 0.43 & 0.48 & r.n. \\
\hline & Lead & 0.19 & 0.24 & 0.21 & 0.01 \\
\hline & Cadmium & 0.37 & 0.38 & 0.38 & r.n. \\
\hline
\end{tabular}

Explanation: see table 5

2. Experimentally cultivated Jerusalem artichoke (Helianthus tuberosus L.), Gigant variety, was found with lower contents of carbon, nitrogen and phosphorus, when compared to other plants grown for biomass.

3. The two year experiment did not indicate any significant effect of the factors (FS and FA) analysed on changes in micronutrients content $(\mathrm{Zn}, \mathrm{Cu}, \mathrm{Ni})$ in the aerial parts of the Gigant variety of Jerusalem artichoke (Helianthus tuberosus L.). The use of municipal sewage sludge (FS) led to cadmium increases within the first year of research as well as lead content in the second year. Wood ash fertilization (FA) did not indicate any impact on cadmium and lead content in the green biomass of Jerusalem artichoke. The content of these elements did not, however, exceed the limits provided in the European Commission Regulation (UE) NR 1275/2013 concerning maximum levels of cadmium and lead in animal feeds.
4. The contents of some metals (zinc, copper, lead and cadmium) in the aerial parts of Jerusalem artichoke did not exceed the value limits for wood pellets and briquettes provided in applicable standards of the Deutsches Institut für Normung [DIN 51731 1996-10]. It thus means that this plant materials that comply with safety standards are suitable for energy uses.

5. The field experimentation has demonstrated that both components namely, ash obtained from wood biomass and municipal sewage sludge that comply with legislative requirements such as Regulation of the Minister of Environment of 13 July 2010 on municipal sewage sludge [Journal of Laws 2010 No. 137 item 924] and Regulation of the Minister of Agriculture and Rural Development on the implementation of certain provisions of the act on fertilizers and fertilizing [Journal of Laws 2008 No. 119 item 765], constitute a valuable fertilizing substance if returned to the soil in ac- 
cordance with the ideals of sustainable development. It ensures adequate growth conditions for the Gigant variety of Jerusalem artichoke (Helianthus tuberosus L.) thus completing the all-embracing circulation cycle of elements in the local ecosystem.

6. The comprehensive activities involving the cultivation of Jerusalem artichoke (Helianthus tuberosus L.) for energy purposes, using municipal sludge and ash from wood biomass as fertilizers could serve as tools for retardation of negative environmental transformation by reducing the amount of $\mathrm{CO}_{2}$ emitted in the environment, recycling of waste materials as well as limiting the exploitation of non-renewable resources.

\section{REFERENCES}

1. Börjesson P. 1996. Energy analysis of biomass production and transportation, Biomass and Bioenergy, 11(4), 305-318.

2. Borkowska H., Lipiński W. 2008. Comparison of content of selected elements in biomass of Sida hermaphrodita grown under various soil conditions, Acta Agrophysica, 11(3), 589-595.

3. Budzyński W., Bielski S. 2004. Energy resources of agricultural origin Part II. Biomass as a solid fuel (review), Acta Science Polish, Agricultura 3(2), 15-26.

4. Chabbert N., Guiraud J.P., Arnoux M., Galzy P.1985. Productivity and fermentability of different Jerusalem artichoke (Helianthus tuberosus) cultivars. Biomass 6, 271-284.

5. Commission Regulation (EU) No 1275/2013 of 6 December 2013 amending Annex I to Directive 2002/32/EC of the European Parliament and of the Council as regards maximum levels for arsenic, cadmium, lead, nitrites, volatile mustard oil and harmful botanical impurities.

6. Conde J.R., Tonatio J.L., Rodriguez-Maribona B., Lansac R., Ayerbe L. 1991. Tuber yield of Jerusalem artichoke (Helianthus tuberosus L.) in relation to water stress, Biomass and Bioenergy, 1(3), 137-142.

7. Curt M.D., Aguado P., Sanz M., Sánchez G, Fernández J. 2006. Clone precocity and the use of Helianthus tuberosus L. stems for bioethanol, Industrial Crops and Products 24, 314-320.

8. DIN 51731. 1996-10. Prüfung fester Brennstoffe - Preßlinge aus naturbelassenem Holz - Anforderungen und Prüfung. CERTCO Deutsches Institut für Normung (DIN).
9. Hartmann H., Produktion, Bereitstellung und Eigenschaften biogener Festbrennstoffe.2014 W: Leitfaden Feste Biobrennstoffe Planung, Betrieb und Wirtschaftlichkeit von Bioenergieanlagen im mittleren und grosen Leistungsbereich. 89(4) 17-53.

10. Helios W., Kozak M., Malarz W., Kotecki A. 2014. Effect of sewage sludge application on the growth, yield and chemical composition of prairie cordgrass (Spartina pectinata Link.), Journal of Elementology. DOI: 10.5601/jelem.2014.19.3.725, 1021-1036.

11. Jankowska-Huflejt H. 2014. Nutritive value and the content of macroelements in fodder and in soil from organic grasslands. Journal of Research and Applications in Agricultural Engineering. 51(3), 91-97.

12. Jeroch H., Flachowsky G., Weissbach F.1993. Futtermittelkunde. Fischer Verlag Jena, Stuttgart, $1-510$.

13. Journal of Laws 2008 No. 119 item 765 - Regulation of the Minister of Agriculture and Rural Development on the implementation of certain provisions of the act on fertilizers and fertilizing.

14. Journal of Laws 2010 No. 137 item 924 - Regulation of the Minister of Environment of 13 July 2010 on municipal sewage sludge.

15. Kabata-Pendias A. 2011. Trace elements in soil and plants. CRC Press, Taylor\&Francis (ed), 4, 1-550.

16. Komorowicz M., Wróblewska H., Pawłowski J. 2009. Chemical composition and energetic properties of biomass from selected renewable resources, Ochrona Środowiska i Zasobów Naturalnych. 40, 402-410.

17. Kostecka J. 2010. Retardacja przekształcania zasobów przyrody jako element zrównoważonego rozwoju. [w:] Kostecka J. (red.), Retardacja materialnego przekształcania zasobów przyrodniczych. Osiągnięcia, problemy, perspektywy. Biuletyn KPZK PAN. 242, 27-49.

18. Kostecka J. 2013. Self evaluation on the way to retardation of pace of life and resources transformation. Problems of Sustainable Development. 8(2), 93-102.

19. Kotecki A. 2010. Uprawa miskanta olbrzymiego. Energetyczne i poza energetyczne możliwości wykorzystania słomy. Wyd. Uniwersytetu Przyrodniczego we Wrocławiu, 1-186.

20. Kowalczyk-Juśko A. 2013. Biometryczne i energetyczne parametry spartiny preriowej (Spartina pectinata Link.) w trzech pierwszych latach wegetacji. In: Roblemy Inżynierii Rolniczej (IV-VI), 69-77.

21. Kozak M., Kotecki A., Dobrzański Z. 2006. The Miscanthus giganteus response to chemical contamination of soil. In: Górecki H. (red.) Chemistry 
and biochemistry in the agricultural production and environment protection. Czech-Pol-Trade, Prague, 520-524.

22. Kristensen E.F. 2003. Harvesting and handling of miscanthus - Danish experiences. Proc. 1st meeting of IEA-Bioenergy Task 30, Denmark, September 22-25. In: Jřrgensen U., Verwijst T. (eds.), DIAS report - Plant Production, 86, 41-46.

23. Kulik M. 2009. Effect of different factors on chemical composition of grass-legumes sward, Journal of Elementology Journal of Elementology 14(1), 91-100.

24. Kwaśniewski D., Mudryk K., Wróbel M. 2010. Plantacje roślin energetycznych. In: Produkcja biomasy na cele energetyczne, red. J. Frączek wyd. PTIR Kraków, 59-74.

25. Kwiatkowski J. 2012. Byliny. In: Wieloletnie rośliny energetyczne. Red. nauk. Szczukowski S. MULTICO Oficyna Wydawnicza, 105-122.

26. Official Journal of the European Union. 5.6.2009. L 140/16 Directive (EU) 2009/28/EC of the European Parliament and of the Council of 23 April 2009 on the promotion of the use of energy from renewable sources and amending and subsequently repealing Directives 2001/77/EC and 2003/30/EC.

27. Podkówka Z. 2012. Prognoza zapotrzebowania na biopaliwa ciekłe i energię elektryczną w Polsce. In: Biogaz rolniczy odnawialne źródło energii. Teoria i praktyczne zastosowanie. Red. W. Podkówka., PWRiL Sp. z o.o. Warszawa, 39-49.

28. Popczyk J. 2008. Rola biomasy i polskiego rolnictwa w realizacji Pakietu energetycznego. Czysta Energia 2, 18-20.

29. Poskrobko B. 2010. Nowe podejście do bogactwa przyrodniczego jako podstawa retardacji wykorzystania zasobów. In: Kostecka J. (red.), Retardacja materialnego przekształcania zasobów przyrodniczych. Osiągnięcia, problemy, perspektywy. Biuletyn KPZK PAN, 242, 50-64.

30. Poskrobko B., Kostecka J. 2016. Retardacja W świadomości społecznej. Polish Journal for Sustainable Development. 20. 145-160. DOI: 10.15584/pjsd.2016.20.16
31. PN-EN 15104:2011(U) - Solid Biofuels - Determination of total content of carbon. Hydrogen And Nitrogen - Instrumental Methods.

32. PN-R-04022:1996/Azl:2002 Chemical and agricultural soil analysis - Determination of available potassium in mineral soils

33. Sawicka B., Kalembasa D., Skiba D. 2015. Variability in macroelement content in the aboveground part of Helianthus tuberosus L. at different nitrogen fertilization levels. Plant Soil Environment, 61(4) 158-163. DOI: 10.17221/956/2014-PSE.

34. Scholz V., Ellerbrock R. 2002. The growth productivity, and environmental impact of the cultivation of energy crops on sandy soils in Germany. Biomass and Bioenergy 23(2), 81-92.

35. Skiba D. 2014. Variability in yield and quality of selected features several varieties of Helianthus tuberosus L. under different fertilization. [Ph.D. Thesis]. University of Life Sciences in Lublin.

36. Slepetys J., Kadziuliene Z., Sarunaite L., Tilvikiene V., Kryzeviciene A. 2012. Biomass potential of plants grown for bioenergy production, International scientific conference Renewable Energy and Energy Efficiency. Jelgava, Latvia, 66-72.

37. Stanley J.K., Nottingham S.F. 2007. Biology and Chemistry of Jerusalem Artichoke: Helianthus tuberosus L. CRC Press ISBN1420044966, 9781420044966, 35-51.

38. Stolarski M.J., Krzyżaniak M., Waliszewska B., Szczukowski S., Tworkowski J., Zborowska M. 2013. Lignocellulosic biomass derived from agricultural land as industrial and energy feedstock In: Wood research papers, research papers announcements - Wood Technology Institute, Poznań 56(189), 5-22.

39. Szczukowski S., Stolarski M. 2013. Plantacje drzew i krzewów szybko rosnących jako alternatywa biomasy z lasu - stan obecny, szanse i zagrożenia rozwoju. Biomasa leśna na cele energetyczne. red. nauk. Gołos P., Kaliszewski A. IBL Sękocin Stary, 32-46.

40. Wandrasz J.W., Wandrasz A.J. 2006. Paliwa, formowane biopaliwa i paliwa z odpadów w procesach termicznych. Wyd. Seidel-Przywecki Warszawa. 